\title{
Infraestrutura Verde em São Paulo: o caso do Corredor Verde Ibirapuera-Villa Lobos
}

Green Infrastructure in São Paulo - the case of the Ibirapuera-Villa Lobos Green Corridor

\section{Maria de Assunção Ribeiro Franco}

Professora Titular do Departamento de Projeto da Faculdade de Arquitetura da Universidade de São Paulo.

Coordenadora do Laboratório LABVERDE e Editora da REVISTA LABVERDE.

mariafranco@usp.br

\section{Resumo}

Este trabalho desenvolve o conceito de infraestrutura verde aplicada ao sistema de espaços verdes da Cidade de São Paulo e mais especificamente tendo por área de estudo a várzea do Rio Pinheiros. Neste caso consideram-se como áreas núcleo da infraestrutura verde os parques Ibirapuera e Villa Lobos unidos num grande corredor verde estruturado por ciclovias e caminhos de pedestres em calçadas ecológicas, percorrendo vários distritos entre Moema e Vila Leopoldina (na margem direita) e Morumbi e Butantã (na margem esquerda), entrelaçados em bairros-jardins e pontilhados de praças, áreas institucionais, clubes e zonas de intensa atividade sócio-cultural.

Palavras-chave: Infraestrutura verde, corredor verde, planejamento ambiental, desenho ambiental, desenvolvimento sustentável, resiliência urbana, baixo carbono, mudanças climáticas, parques, áreas verdes, transporte não poluente, modo-de-andar-a-pé, ciclovias, qualidade ambiental.

\section{Abstract}

The present work develops the concept of Green Infrastructure applied to the system of green spaces in São Paulo city, focusing, more specifically, the area of the Pinheiros River valley. Particularly considers the Ibirapuera and Villa Lobos parks as the main core areas of the green infrastructure, which are joined by a great Green Corridor, structured by bike lanes and ecological pavements pedestrian paths, covering several areas of Moema and Vila Leopoldina districts (at right shoulder) as well as Morumbi and Butantã (at left shoulder), alternated 
with garden districts and dotted with parks, institutional areas, clubs and zones of intense socio-cultural activities.

Keywords: green infrastructure, green corridor, environmental planning ,environmental design, sustainable development, urban resilience, low carbon, climate change, parks, green areas, green transport, footing mode, bike lanes, environment quality.

\section{Introdução}

Este artigo é produto ligado à pesquisa "Parques e Áreas Verdes Resilientes na Cidade de São Paulo", iniciada no LABVERDE em 2009, cujo objetivo principal é o de verificar em que medida os parques urbanos e suas bordas podem tornar-se fatores de resiliência e adaptação da Cidade de São Paulo, enquanto ecossistema urbano, às mudanças climáticas. Para tanto serão considerados diversos fatores que tornam os parques o ponto focal da pesquisa quais sejam: o tamanho, a forma, a biodiversidade, situação topográfica, as características de borda (tecidos urbanos adjacentes e pressões urbanas existentes), a distância dos mesmos a outras áreas verdes do entorno, a relação com corpos d'água (existência ou proximidade a nascentes, rios, canais, lagos e represas) e aos tipos de uso que os tornam "prestadores de serviços à cidade", dando-lhe qualidade ambiental.

As áreas verdes consideradas como infraestrutura urbana neste estudo são: parques; praças; ruas, avenidas e espaços verdes junto ao sistema viário; áreas verdes privadas; cemitérios; orlas (bordas d'água de rios). Neste estudo o recorte espacial prende-se a perímetros ligados à administração urbana da cidade de São Paulo, sendo considerado seu perímetro urbano municipal e seus perímetros distritais (de bairro). O recorte temporal prende-se basicamente às três últimas décadas, isto é, décadas de oitenta e noventa do século vinte e primeira década do século vinte e um.

Como ponto de partida, foi selecionada uma área e estudo, entre a zona sul e oeste da Cidade de São Paulo, estruturada na bacia do Rio Pinheiros, tendo como perímetro, a linha de cota limítrofe do antigo cordão meândrico de sua várzea essa área foi então denominada "Corredor Verde Ibirapuera-Villa Lobos". Assim, foram destacados parques e áreas verdes considerados "áreas núcleo" desse mesmo corredor, quais sejam: dois parques de grande porte - Parque do Ibirapuera e o Parque Villa Lobos- na margem direita; dois parques de pequeno porte - o Parque do Povo e o Parque Alfredo Volpi- o primeiro na margem direita e o segundo na margem esquerda; e duas áreas institucionais de grande porte - a Cidade Universitária e o Instituto Butantã - ambos na margem esquerda do Rio Pinheiros. No estudo, as áreas e sítios de borda das áreas núcleo quais sejam praças, ruas arborizadas, clubes, áreas institucionais e bairros jardins - foram considerados como áreas estratégicas de ancoragem para o desenho ambiental urbano, tratado como infraestrutura verde e estruturado no Corredor Verde Ibirapuera-Villa Lobos. 
As referências que empregamos neste artigo prende-se a trabalhos anteriores expressos no livro de FRANCO ${ }^{19}$, bem como as obras de: DRAMSTAD, OLSON e FORMAN -"Landscape Ecology Principles in Landscape Architecture and LandUse Planning" ; PICKETT CADENASSO e GROVE no trabalho "Resilient Cities: Meaning, Models and Metaphor for Integrating the Ecological, Sócio-economic, and Planning Realms"; BENEDICT e McMAHON em Green Infrastructure: Linking Landscapes and Communities; NEWMAN, BEATLEY e BOYER em Resilient Cities: Responding to Peak Oil and Climate Changes.

Logo este trabalho é antes de tudo uma prospecção sobre os conceitos de: planejamento ambiental, desenho ambiental, infraestrutura verde, resiliência, e baixo carbono, dentro da grande linha de pesquisa em mudanças climáticas, aplicadas à cidade de São Paulo, utilizando-se o método de "Criação de Cenários Ambientais" utilizado por FRANCO ${ }^{20}$. Para tanto foi escolhido um setor considerado mais apto à aplicabilidade desses conceitos, na atualidade, por vários fatores, entre os quais a localização em área de várzea, em topografia plana ou com baixa declividade; o fator sócio-econômico privilegiado ${ }^{21}$ em relação ao resto da cidade e o fator de melhor infraestrutura cinza. Logo essas idéias, se aplicadas no presente momento, à nossa área de estudo, teriam maior possibilidade de visualização e realização a curto prazo. A médio e longo prazo inúmeras outras áreas da Cidade de São Paulo poderão ampliar este estudo trazendo novos desafios e possibilidades

\section{Sobre os conceitos de Resiliência e Infraestrutura Verde}

\section{Resiliência Ecológica}

Os estudos e pesquisas referentes às mudanças ambientais e à dinâmica evolutiva tratam das transformações que os sistemas ambientais têm sofrido ao longo dos últimos séculos. Assim, as atividades econômicas e sociais empreendidas pelas sociedades ocasionaram repercussões nos sistemas geomorfológicos e hidrológicos e mudanças significativas nos sistemas ambientais, cujos impactos provocam alterações drásticas e abruptas, talvez irreversíveis, no clima de nosso planeta, portanto, para tratarmos de Infraestrutura Verde torna-se necessário nos aproximarmos do conceito de resiliência.

A estrutura dos sistemas ambientais normalmente respeita uma organização cujo funcionamento depende das forças externas que afetam o equilíbrio ou a estabilidade a que os ecossistemas estão normalmente ajustados. Diante desse contexto, resiliência poderia ser definida como a capacidade do ecossistema em

\footnotetext{
${ }^{19}$ FRANCO, Maria de Assunção Ribeiro - Planejamento Ambiental para a Cidade Sustentável.

${ }^{20}$ FRANCO, op. cit. p.182-184, e cap. IX - São Paulo uma Megacidade Sustentável.

${ }^{21}$ Atlas Ambiental do Município de São Paulo- vejam-se as cartas do Município nas folhas: , 16 Perfil Socio Econômico - e 18 - Perfil Sócio Ambiental.
} 
manter ou retornar às suas condições originais após um distúrbio provocado por forças naturais ou pela ação humana.

Para GUNDERSON ${ }^{22}$ resiliência é fundamental no entendimento e na dinâmica de sistemas de recursos complexos, organizados pelas interações de um grupo de sistemas nos aspectos - ecológico, social e econômico - através de uma série de escalas, onde podem ocorrer vários tipos de vulnerabilidades, choques e rupturas. Assim a resiliência mede a força da mútua cooperação entre processos, incorporando ambos, a habilidade de um sistema de persistir apesar das rupturas e a habilidade para regenerar-se e manter a organização existente.

Lidar com a resiliência ecológica de ecossistemas específicos, mais que otimizar recursos, envolve a compreensão das vulnerabilidades e incertezas que podem ocorrer, e que devem informar políticas de desenvolvimento e proporcionar evidências mais seguras para a tomada de decisão. O conhecimento da resiliência dos ecossistemas é extremamente importante por focalizar os limiares além dos quais os sistemas ecológicos não podem mais se recuperar ou voltar ao estado original, além de que a readequação dos fatores será em relação a um novo equilíbrio, que significa a estabilidade rompida, e a impossibilidade de recuperação dos sistemas naturais.

Como exemplo podemos citar ZAKIA ${ }^{23}$, segundo a qual o conceito chave para o estabelecimento de um plano de manejo sustentável de plantações florestais, por exemplo, deve necessariamente estar baseado no ecossistema. $O$ manejo florestal sustentável de plantações florestais, dentro do princípio da manutenção da integridade do ecossistema, como sendo aquele baseado, ou planejado, em termos da manutenção dos valores da microbacia hidrográfica, sem os quais não há condições de resiliência ecológica. Portanto, uma revisão sobre o conceito de resiliência ecológica, a resiliência do ecossistema ripário, definida como a quantidade de alteração que o mesmo pode absorver sem mudar seu estado, depende, em primeiro lugar, da diversidade dos grupos funcionais que definem a composição e a estrutura da vegetação ripária. Logo, quando este ecossistema perde resiliência, torna-se mais vulnerável a perturbações, que de outro modo seriam normalmente absorvidas. Neste sentido, a gradativa perda de resiliência dos ecossistemas ripários e toda a degradação hidrológica decorrente dela foi, sem dúvida, um dos impactos ambientais mais evidentes do sistema tecnocrata de uso dos recursos naturais, que procurou maximizar a produtividade através do controle de toda fonte externa de variabilidade. Ou seja, as incertezas características dos sistemas naturais foram substituídas pela certeza do controle.

Segundo GUNDERSON ${ }^{24}$, o resgate de uma estratégia mais sistêmica de manejo passa, antes de tudo, pela agregação de resiliência aos ecossistemas ripários, que pode ser conseguido através dos seguintes mecanismos, os quais não

\footnotetext{
${ }^{22}$ GUNDERSON, Lance H. et alii, in Resilience and the Behavior of Large-Scale Systems p.6.

${ }^{23}$ ZAKIA, Maria José Brito et alii, em Plano De Manejo Sustentável de Plantações Florestais; Plano Diretor de ordenamento territorial do Município de Joanópolis - SP (2006).

${ }^{24}$ GUNDERSON,Op. cit.
} 
operam isoladamente, quais sejam: o aumento de sua capacidade tampão; o sistemas de manejo que levam em conta os processos ecológicos em múltiplas escalas (não basta apenas manter a mata ciliar); e a existência de fontes de renovação, também chamados núcleos de vida, ou seja o manejo que leva em conta a permanência da biodiversidade na escala da paisagem.

\section{Resiliência Cultural e Urbana}

Ao adaptar-se o conceito de resiliência ecológica ao campo cultural, é de se supor que "resiliência cultural" é a capacidade que um determinado grupo social tem em resistir a mudanças provocadas pelo choque com culturas diferentes, preservando seu patrimônio cultural. Embora não seja de se esperar que a cultura de uma determinada comunidade permaneça intacta, mesmo porque isso é impossível, no entanto a resiliência, neste caso, está relacionada à permanência de certos códigos simbólicos partilhados por esse grupo, os quais se mantêm, mesmo após a forte influência de uma cultura exótica.

A resiliência refletiria, assim, a persistência das relações internas do sistema, e a capacidade do mesmo voltar às condições originais após ser impactado por forças externas a ele. O conceito de resiliência é muito importante para os cientistas, políticos e administradores em razão do manejo dos sistemas ambientais e em relação às adaptações ou reversibilidade dos impactos antropogênicos.

De acordo com NEWMAN ${ }^{25}$, o cenário de resiliência urbana ocorre quando o acesso a formas alternativas de combustível e edifícios em eco-enclaves, provedores de saúde, permeiam o cenário urbano comum, dando acesso a todos. Nesse caso, as pessoas terão acesso ao trabalho e aos serviços pelo trânsito ou a pé, e especialmente por carros elétricos em trajetos curtos. As conexões interurbanas serão movidas, segundo o autor, pela nova geração de alta interatividade, por meio da rede elétrica, através de alta atividade por vídeoconferência. O projeto da construção verde e os combustíveis renováveis farão parte de todos os bairros. A cidade será desenvolvida por nova rede de ligações por todas as partes da cidade, centros projetados para se andar a pé serão criados através da cidade-região através de grandes infraestruturas e construções verdes. Nas áreas entre os centros e corredores de trânsito e desenvolvimento intenso, serão estabelecidos eco-bairros, para ajudar nas funções ecológicas da cidade, os quais produzirão energia renovável, reciclagem de água e tratamento de esgoto; eles serão ligados aos grandes espaços do sistema de infraestrutura verde, através de um inteligente sistema de manejo local.Surgirão, portanto, ecobairros especializados em produtos agrícolas e áreas de manejo de biodiversidade urbana. Eles serão largamente sustentáveis, mesmo numa distância razoável da cidade, com muitas funções urbanas. ${ }^{26}$

O mesmo autor descreve a cidade resiliente como a cidade das ciclovias e ruas sem carros indo de casas solares para lojas de produtos comestíveis, áreas de

\footnotetext{
${ }^{25}$ NEWMAN, Beatley e Boyer in Resilient Cities: Responding to Peak Oil and Climate Changes p.51.

${ }^{26}$ NEWMAN, Beatley and Boyer, in Resilient Cities, p.53
} 
recreação, parques, bondes elétricos para conduzir para longe do caminhar e da bicicleta, interligando os conjuntos de "escritórios solares", afinados com a "sexta onda de negócios" 27 . Escolas com o pais alinhados sobre suas bicicletas ao invés de esperarem em seus carros ociosos. O mercado da fazenda local para comprar produtos bio-regionais. Para exemplificar, NEWMAN, remete a cena descrita acima ao lugarejo de de Vauban, comunidade formada numa base militar da cidade de Freiburg, na Alemanha, com cinco mil famílias. Assim, segundo o autor, Vauban é considerada uma comunidade ecológica modelar a qual está sendo estudada com crescente interesse como econômica e saudável, tendo como foco a diminuição dos custos da dependência do carro. Onde são oferecidos aos residentes numerosos incentivos (tais como passes de bondes elétricos e opções de largar o carro) e desestimular para dirigir com gasolina a oito dólares por litro. Assim, a competição entre Vauban e os Estados Unidos, na relação de carro por morador, é de 150 veículos para 1000 habitantes em Vauban, comparados aos 640 veículos para 1000 habitantes nas cidades americanas.

Os exemplos descritos anteriormente mostram que para alcançar resiliência a cidade deve mesclar o modo de viver com os transportes sustentáveis, negócios inovadores e fortes políticas de incentivos para a criação ou sustentação de ambientes sustentáveis, do nível regional ao nível local. Isso pode se dar com sete condições chave propostas por NEWMAN: 1- Cidade de Energia Renovável onde áreas urbanas podem ser abastecidas com tecnologias de energias renováveis, do nível regional ao nível do edifício; 2- Cidade de Baixo Carbono onde os edifícios, os lugares e as atividades de negócio sejam de baixo carbono; 3- Cidade Distributiva ou Policêntrica - as cidades deverão mudar dos grandes sistemas de abastecimento de água e tratamento de lixo para sistemas menores de escala local; 4- Cidade Fotossintética com potencialidade para uso de energias renováveis na produção local de alimentos e fibras; 5- Cidade Eco-eficiente - as regiões e cidades deverão mudar seu funcionamento, de sistemas lineares para sistemas circulares de energia e materiais, estes últimos, necessários para a alimentação de economias locais com sentido de lugar; 6- Cidade Baseada no Lugar- as cidades e regiões entenderão que o uso da energia renovável é o caminho para a construção da economia e abastecimento locais, com um sentido de lugar único e especial; 7- Cidade do Transporte Sustentável, onde as cidades e regiões, no uso de energias renováveis, poderão oferecer a facilidade de se andar a pé, e opções de trânsito suplementadas por veículos elétricos.

\footnotetext{
${ }^{27}$ HARGROVES e Smith, appud NEWMAN et Ali, referindo-se às ondas da industrialização que moldaram as cidades. Segundo esse autor as ondas da industrialização são seis: a primeira ligada ao ferro, a energia da água, a mecanização têxtil e o comércio; a segunda ao vapor, à estrada de ferro, ao aço e ao algodão; a terceira à eletricidade, aos produtos químicos e aos engenhos de combustão interna; a quarta aos petroquímicos, a eletrônica, a aviação e o espaço; a quinta às redes digitais, à biotecnologia, ao software, à tecnologia da informação; por último, a sexta onda que é a da sustentabilidade, à produtividade radical dos recursos, o sistema de projeto (design) total, à biotecnologia, à química verde, a ecologia industrial, à energia renovável e à nanotecnologia verde. Para NEWMAN a Cidade Resiliente está no patamar dessa sexta onda.
} 
NEWMAN alerta que, enquanto as cidades não se mostram inovadoras nas sete condições apresentadas acima, pelo menos devem ser avançadas em uma ou duas dessas condições. Assim, a mudança sendo aplicada em todas as cidades resilientes juntas, estará assim, gerando um senso de esperança através da combinação de novas tecnologias, projetos urbanos e comunidades baseadas na inovação. Dessa forma, o ator concebe uma possibilidade das cidades saírem da linha de colapso eminente, num panorama mundial, para um novo patamar mais seguro de sobrevivência e superação da situação atual.

\section{O conceito de Infraestrutura Verde}

Hoje o termo "infraestrutura verde" tornou-se freqüente em conservação e desenvolvimento do solo em todo o mundo. Porém o termo significa diferentes coisas dependendo do contexto no qual ele é empregado: pode ser desde o plantio de árvores que tragam benefícios ecológicos em áreas urbanas; para outros refere-se a estruturas de engenharia tais como manejo de enchentes ou tratamento de águas projetado para tornar-se ambientalmente amigável. No entanto infraestrutura verde pode ter um significado mais ambicioso e abrangente.

No Planejamento e Desenho Ambiental, a Infraestrutura Verde pode ser entendida como uma rede interconectada de áreas verdes naturais e outros espaços abertos que conservam valores e funções ecológicas, sustentam ar e água limpos e ampla variedade de benefícios para as pessoas e a vida selvagem de deverão nortear as ações de planejamento e desenvolvimento territoriais que deve garantir a existência dos processos vivos no presente e no futuro.

O conceito de planejamento e projeto de infraestrutura verde começou há cerca de 150 anos, segundo BENEDICT ${ }^{28}$, o qual cita como ponto de partida, as idéias de Henry David Thoreau, George Perkins Marsh e Frederick Law Olmsted. De acordo com o autor, a idéia de infraestrutura verde contou ao longo do tempo com a contribuição de inúmeras disciplinas que contribuíram com teorias e idéias, pesquisas e conclusões que tem criado um crescente campo de conhecimento. As origens do planejamento da infraestrutura verde estão relacionadas, portanto, a idéias e ações de conservação da natureza através dos parques nacionais estaduais e municipais; refúgios de vida selvagem; florestas; rios áreas úmidas; proteção da vida selvagem; planos de desenvolvimento em relação à natureza em disciplinas de planejamento urbano, planejamento da paisagem $e$ desenvolvimento ambientalmente sensível. $O$ terceiro maior ímpeto da infraestrutura verde foi a criação de "corredores verdes", que foca a atenção no impacto que o desenvolvimento provoca na paisagem. A infraestrutura verde ganha, assim, força com raízes interdisciplinares e multidisciplinares. É preciso ver também, que a infraestrutura verde requer a prioridade da identificação e a ligação das áreas de conservação, através dos corredores verdes.

\footnotetext{
${ }^{28}$ BENEDICT in Green Infrastructure: Linking Landscapes and Communities p. 23-25.
} 
Para entendermos o conceito de infraestrutura verde é importante incorporarmos o conceito de resiliência para isso podemos apresentar o cenário de resiliência apresentado por NEWMAN ${ }^{29}$. Para o autor o cenário de cidade resiliente ocorre com as alternativas de combustível e construções em eco-enclaves, que proporcionam a riqueza para todos num cenário urbano multifacetado. Dessa forma, as pessoas terão acesso a trabalho e serviços por transito ou caminhada, tanto quanto o uso de carros elétricos para pequenos percursos. Os movimentos interurbanos serão movidos por transporte rápido alimentado por rede elétrica e por alta interatividade de meios como a vídeo conferência. Edifícios verdes e energias renováveis farão parte do todas as localidades.

Nas duas últimas décadas cresceu muito no Brasil a idéia do planejamento e projeto de infraestrutura verde com as e o refinamento de práticas de conservação do solo. A adição de idéias do movimento dos corredores verdes traz o envolvimento crescente de uma grande variedade de agencias e pessoas em níveis da comunidade, do nível regional , estado e nação. Um exemplo do pensamento de espaços de preservação com inspiração na teoria dos ecossistemas nos vem da obra de DRAMSTAD ${ }^{30}$ que afirma que o desenho estrutural de uma paisagem ou região é inteiramente composta de três tipos de elementos: matrizes, manchas e corredores, os quais devem orientar tanto 0 planejamento do uso do solo quanto a arquitetura da paisagem.

Infraestrutura verde muda nossas percepções sobre espaços verdes planejados e protegidos. Para muitas pessoas, espaços abertos são simplesmente terra que ainda não está desenvolvida, e espaços verdes refere-se a parques isolados, sítios de recreação e áreas naturais. Infraestrutura verde enfatiza a importância dos espaços abertos verdes como parte de sistemas interconectados que são protegidos e mantidos pelos benefícios ecológicos que eles proporcionam. Enquanto espaço verde é freqüentemente visto como alguma "coisa boa de ter", infraestrutura verde implica alguma "coisa que precisamos ter" que BENEDICT resume como: "proteger e restaurar nosso sistema de suporte de vida natural é uma necessidade, não uma amenidade."31

Para BENEDICT, enquanto o espaço verde é freqüentemente visto como autosustentável, a Infraestrutura Verde implica num espaço verde e num sistema natural que precisa ser ativamente protegido, mantido e, em alguns casos, restaurado. Assim, a Infraestrutura Verde difere dos convencionais enfoques de conservação do solo e proteção dos recursos naturais, porque vê a conservação conectada com desenvolvimento do solo e planejamento de infraestrutura com fins antrópicos. Dentre os princípios definidores da infraestrutura verde citados pelo autor destacamos:

Conectividade - a infraestrutura verde delineia a força do seu foco em conectividade, entre espaços naturais e os parques e outros espaços abertos, entre as pessoas e os programas. A conservação biológica tem demonstrado que

\footnotetext{
${ }^{29}$ NEWMAN et all, in Resilient Cities p. 51

${ }^{30}$ DRAMSTAD, Olson e Forman, in: Landscape Ecology Principles in Landscape Architecture and Land-Use Planning, p. 14.

${ }^{31}$ BENEDICT, op. cit. p.2.
} 
a conexão é essencial para os sistemas naturais desempenharem sua função genuína e para propiciar a vida selvagem. Assim, é de fundamental importância estabelecer a conexão entre os componentes dos ecossistemas - parques, áreas de preservação, áreas ripárias, áreas úmidas e outros espaços verdes- para que eles juntos possam manter valores e serviços dos sistemas naturais, tais como carregar e filtrar água da chuva, e manter a saúde e a diversidade das populações de vida selvagem.

Dessa forma a infraestrutura verde pode ajudar a estabelecer prioridades na aquisição de terra que assegure conectividade adequada entre áreas já preservadas.

Contexto -o entendimento dos ecossistemas e da paisagem requer uma análise do contexto onde esses ecossistemas existem isto é a compreensão dos fatores físicos e biológicos das áreas de entorno.

Estrutura -A Infraestrutura verde pode funcionar com estrutura para a conservação e o desenvolvimento.

Comprometimento - a infraestrutura verde requer comprometimento de longo prazo por parte do governo e dos agentes sociais.

\section{Benefícios da Infraestrutura Verde}

Podemos considerar infraestrutura verde como sendo áreas urbanas permeáveis ou semi-permeáveis, plantadas ou não que "prestam serviços" à cidade e apresentam algum grau de manejo e gerenciamento púbico ou privado. Das área pertencentes à infraestrutura verde de uma cidade destacamos os seguintes serviços prestados:

1- Melhora da qualidade do ar promovendo a saúde humana;

2- Seqüestro de carbono da atmosfera;

3- Amortização do balanço climático entre temperaturas baixas e altas no microclima urbano entre dia-noite e as estações do ano;

4- Proteção, conservação e recuperação da biodiversidade da flora e fauna na área urbana;

5- Contenção da erosão;

6- Promoção de atividades contemplativas, esportivas e de lazer;

7- Promoção da importância da paisagem como fator determinante da estética urbana;

8- Incremento do fator permeabilidade do solo urbano permitindo a percolação da água e portanto a redução de enchentes;

9- Articulação e conectividade entre espaços verdes;

10- Promoção da seguridade urbana;

11 - Proteção de áreas de fragilidade ecológica; 
12- Promoção de áreas de alto valor imagético, icônico e de identidade de lugares e sítios urbanos.

\section{Corredores Verdes}

O conceito de corredores verdes surgiu nas ultimas décadas do século XX na Europa e Estados Unidos, inspirado nos "corredores ecológicos", e respondendo à premência de compatibilização dos efeitos nefastos da expansão urbana e à conseqüente necessidade de preservar a qualidade ambiental nas cidades.

Os corredores verdes, portanto, são definidos como uma rede de espaços lineares servindo a usos múltiplos, preferivelmente, acompanhando corredores ecológicos. Dessa forma prestam-se a essa função as beiras d'água, tanto costeiras quanto continentais, as linhas de cumeeira, fundos de vale e áreas de alta declividade. Assim os corredores verdes ligam grandes e pequenas áreas protegidas, os corpos d'água e áreas úmidas os sítios de significado histórico e cultural.

Os corredores verdes ganham força ao formarem redes de mobilidade segura, dando prevalência ao pedestre e aos meios de transporte movidos a energia não poluente, recuperando a memória de antigos caminhos e trilhas e incorporando 0 valor paisagístico dos percursos e sítios notáveis. Aí entra em cena de forma contundente a idéia da liberação da dependência do automóvel, o uso da bicicleta e o andar a pé.

Nas duas últimas décadas cresceu muito no Brasil a idéia do planejamento e projeto de infraestrutura verde com as e o refinamento de práticas de conservação do solo. A adição de idéias do movimento dos corredores verdes traz 0 envolvimento crescente de uma grande variedade de instituições e pessoas em níveis da comunidade, no âmbito regional, estadual e nacional.

\section{Infraestrutura Verde em São Paulo}

A rigor o verde existente em São Paulo não foi pensado como infraestrutura verde, no entanto a Cidade apresenta um grande conjunto de categorias de áreas verdes incluindo, no setor público, áreas de proteção, parques, praças, ruas e avenidas arborizadas e áreas institucionais; e, no setor privado, clubes, áreas particulares e bairros jardins. Assim, essas áreas verdes, pontuam a imensa mancha cinzenta, de área construída contínua da Metrópole, visível nas imagens de satélite, como pequenas e médias "ilhas", contrastando com o verde intenso da Mata Atlântica a leste e sudeste (na Serra do Mar) e a norte e noroeste com o verde da Serra da Cantareira e do Parque do Jaraguá.

Tanto nas imagens de satélite quanto nos mapas da Cidade, fica flagrante a escassez das mesmas diante da massa construída, denunciando uma taxa de 
área verde por habitante bastante prejudicada (cerca de $2,5 \mathrm{~m}^{2}$ por habitante) em relação à taxa recomendada pela UNESCO, que é de $12,00 \mathrm{~m}^{2}$ por habitante.

A nosso ver há uma necessidade urgente de mudança de mentalidade por parte do governo e da população, em relação às áreas verdes da Cidade de São Paulo, na direção do conceito de infraestrutura verde.

Como infraestrutura verde entende-se que as áreas verdes existentes e futuras devem ser organizadas e entendidas como redes verdes interconectadas, tendo nos grandes parques e áreas protegidas suas "áreas-núcleo" principais, nos parques lineares, ruas e avenidas arborizadas seus "corredores verdes", funcionando como tentáculos ou "links" de conexão.

A infraestrutura verde ganha eficiência quando suas ligações - os corredores verdes - contam com meios de transporte não motorizado e não poluente, como o modo de andar a pé e o transporte ciclo-viário, apoiado pela infraestrutura viária e metroviária eficientes. Além disso a infraestrutura verde deve estar conectada e entrelaçada à rede de espaços culturais de esporte e lazer de cada distrito e da Cidade em geral.

\section{O Corredor Verde Ibirapuera-Villa Lobos}

Neste estudo de caso foi delimitada um trecho da várzea do Rio Pinheiros compreendendo, na margem direita, os distritos de Moema, Itaim-Bibi, Jardim Paulista, Pinheiros, Alto de Pinheiros e Vila Leopoldina (este último, como ligação intersetorial entre nossa área de estudo e outros distritos do setor oeste da Cidade de São Paulo); e na margem esquerda, os distritos do Morumbi e Butantã. Essa área, como um todo, foi denominada Corredor Verde Ibirapuera-Villa Lobos onde foi elaborado um Cenário de Planejamento e Desenho Ambiental onde se projetou uma Infraestrutura Verde dentro do conceito de Resiliência Urbana ${ }^{32}$.

Os parques e áreas institucionais considerados como Núcleos Verdes da Infraestrutura Verde, neste trabalho, obedecem aos seguintes critérios:

a) tamanho - (medido em hectares), sendo o maior de aproximadamente 416,56 ha (Cidade Universitária - CUASO), um de médio porte com cerca de 73,20 há (o Parque Villa Lobos), um de pequeno porte com cerca de 11,20 há (Parque do Povo - Parque Mário Pimenta Camargo) Fig. 1;

\footnotetext{
32 Neste caso o Cenário do Corredor Verde Ibirapuera-Villa Lobos segue o caminho inverso do proposto por BENEDICT in op. cit., Lembremos que uma das premissas mais importantes, para o autor, é de que a Infraestrutura Verde deve ser planejada antes que o desenvolvimento aconteça,e no caso da Várzea do Pinheiros, nós estamos trabalhando sobre uma área já totalmente impactada e poluída pelo desenvolvimento.
} 
b) forma - A forma de um parque é muito importante pois ela pode determinar a sua resiliência ou não, uma vez que formas muito estreitas, por exemplo, estão impossibilitadas de abrigar núcleos coesos de relações bióticas.

c) disposição em relação ao relevo e à bacia hidrográfica à qual pertencia, quais sejam: posição em cumeeira, média encosta ou fundo de vale; presença de áreas núcleo ricas em biodiversidade;

d) pressão de borda a que cada um dos parques está sujeito, sejam áreas densamente construídas e verticalizadas, bairros horizontais com arborização urbana significativa, bairros jardins, bairros horizontais de baixa renda ou favelas;

e) equipamentos disponíveis ao uso público tais como áreas esportivas áreas de lazer, áreas de contemplação ou áreas edificadas dedicadas à ciência e à cultura, como exposições, museus e teatros;

f) valor imagético, simbólico e cultural de cada parque ou área institucional, em relação ao público freqüentador, o qual pode abranger múltiplas escalas de influência.

Assim, a Infraestrutura Verde no Corredor Verde Ibirapuera-Villa Lobos, conta com os seguintes elementos: Núcleos Verdes - os Parques e Áreas Institucionais descritas acima; Ligações Verdes - ruas e avenidas arborizadas; corpos d'água existentes (Rio Pinheiros, Raia Olímpica da Cidade Universitária, conjunto lacustre do Parque do lbirapuera) e propostos (ribeirões nos Parques Lineares P1, P2, P3 e P4); e com a rede de caminhos de mobilidade ecossocial, composto por calçadas ecológicas ${ }^{33}$ e sistema de ciclovias que, inclusive, incorpora as ciclofaixas existentes e projetadas (fig.2 e 3 ).

O Corredor Verde Ibirapuera-Villa Lobos, portanto, foi estruturado primeiramente na bacia hidrográfica do Rio Pinheiros (hoje Bacia de Drenagem do Rio Pinheiros), e a seguir ancorada nas áreas verdes de grande e médio porte existentes quais sejam: O Parque do Ibirapuera, o Parque Villa Lobos, o Parque do Povo, o Parque Alfredo Volpi, o Instituto Butantã e a Cidade Universitária (Fig. 2 e 3), considerados como Núcleos Verdes de alto valor ecológico e sócio-cultural.

Num segundo momento foram criados quatro parques lineares que resgatam a memória de quatro ribeirões contribuintes do Rio Pinheiros, que foram total ou parcialmente tubulados e subtraídos da paisagem, pelo sistema de drenagem na várzea do Rio Pinheiros (Fig. 3), quais sejam: o P1 junto ao Ribeirão do Sapateiro, e o P2 junto ao Ribeirão das Corujas, na margem direita; e o P3 junto ao Ribeirão Pirajuçara, e o P4 junto ao Ribeirão do Jaguaré, na margem esquerda, estes últimos, balizando a Cidade Universitária e o Instituto Butantã.

Num terceiro momento foi criada uma rede de caminhos de mobilidade ecossocial que privilegiam o andar-a-pé e de bicicleta e, portanto, enaltecem o pedestre ao criar calçadas ecológicas seguras e sinalizadas, e o ciclista com a criação de um

\footnotetext{
${ }^{33}$ Entendam-se por calçadas ecológicas as calçadas que garantam o caminhar seguro por parte dos pedestres, com sinalização e revestimentos apropriados, bem como contem com um projeto que premie a arborização massiva com espécies apropriadas, a permeabilidade com infraestruturas que permitam a existência de biovaletas e jardins de chuva.
} 
sistema integrado de ciclovias. Esses caminhos foram traçados dentro dos seguintes critérios:

1. ligações com os parques e áreas verdes principais;

2. circuitos projetados sobre topografia plana ou de baixa declividade;

3. Traçado ao longo de ruas e avenidas arborizadas, com calçadas largas e, preferivelmente, com canteiro central;

4. circuitos que percorrem bairros-jardins, considerados como zonas de amortecimento ou buffer zones dos parques e áreas verdes principais (fig. 4);

5. Circuitos que percorrem setores com grande intensidade de atividades culturais, de lazer, turismo e negócios;

6.circuitos integrados com infraestrutura ferroviária e metroviária, considerados meios de transporte de energia limpa, no caso a CPTM e o Metro (figura-3);

7. circuitos que enfatizam pontos relevantes da cultura paulistana como: o Monumento às Bandeiras, no Parque do Ibirapuera, a Igreja Nossa Senhora do Brasil, na Av. Brasil; os museus da Casa Brasileira e Tomie Ohtake, na Av. Faria Lima;

8. pontos de visibilidade paisagística, como o mirante da Praça do Por-do-Sol (Praça Coronel Custódio Pinheiro), ou a visão das pontes sobre o Rio Pinheiros;

9. pontos de proximidade com as águas, junto à ciclo-faixa projetada na margem direita desde a Represa Guarapiranga até o Parque Vila Lobos, bem como nos futuros parques lineares propostos P1, P2, P3, e P4 (fig. 3);

10. sítios e caminhos históricos, como o Largo da Batata, o Largo de Pinheiros, o Caminho dos Pinheiros e a Estrada da Boiada;

11. ponte de pedestres,com ciclovia sobre o Rio Pinheiros e as Marginais, unindo o P2 - Parque das Corujas - no trecho onde hoje é a Av. Professor Frederico Herman Junior, junto à Av. Nações Unidas - com o Bairro do Butantã.

O estudo de mobilidade ecossocial do experimento - Corredor Verde Ibirapuera Vila Lobos - torna essencial a criação de um quinto Parque Linear, acompanhando o rio Pinheiros com as necessárias transposições (pontes de pedestres e bicicletas), sendo que uma delas está prevista na continuação do Parque das Corujas, unindo os bairros de Pinheiros e Alto de Pinheiros ao do Butantã. 
Fig. 1 - Tabela de Parques e Áreas Institucionais selecionadas como Áreas Núcleo do Corredor Verde Ibirapuera-Villa Lobos

\begin{tabular}{|l|l|l|l|}
\hline № & Parque & Gestão & Área/ha \\
\hline 1 & Parque do Ibirapuera & Municipal & 158,40 \\
\hline 2 & Parque Villa Lobos & & \\
\hline & & Estadual & 73,20 \\
\hline 3 & Parque Alfredo Volpi & & \\
\hline & & Municipal & 14,24 \\
\hline 4 & Parque do Povo (Mário Pimenta Camargo) & Municipal & 11,20 \\
\hline & & & \\
\hline & & & \\
\hline & Áreas Institucionais & & \\
\hline 5 & Cidade Universitária (CUASO) & Estadual & 416,56 \\
\hline & & & \\
\hline 6 & Instituto Butantan & Estadual & 74,75 \\
\hline & & & \\
\hline
\end{tabular}

\section{Resiliência Urbana - Apropriação Ecossocial da Várzea do Rio Pinheiros}

O Corredor verde Ibirapuera-Villa Lobos surge dentro de um ideário por parte dos cidadãos paulistanos de "reconquista das várzeas", e no caso deste trabalho, a "reconquista da várzea do Rio Pinheiros". Como é sabido, o rio Pinheiros teve suas várzeas fortemente transformadas no correr do século $X X$, pelas obras de retificação e canalização das obras de inversão de seu curso, o qual passou a 
alimentar as Represas Guarapiranga e Billings para a produção de energia elétrica em Cubatão. Nesse processo, perderam-se todas as áreas úmidas, ao longo de seu cordão meândrico original, em decorrência dos aterros e obras de drenagem ali realizadas, e que acabaram por subtrair da paisagem todos os cursos d'água contribuintes do rio maior, reduzindo-os a meros tubos de escoamento de águas, soterrados debaixo das "avenidas de fundo de vale". Com isso, é certo, foram ganhas ao rio enormes glebas de terreno, muitas delas habilmente reunidas pela Companhia City no planejamento dos Bairros Jardins, situados hoje nos bairros em estudo, de Moema, Jardim Paulistano, Pinheiros, Alto de Pinheiros e Vila.

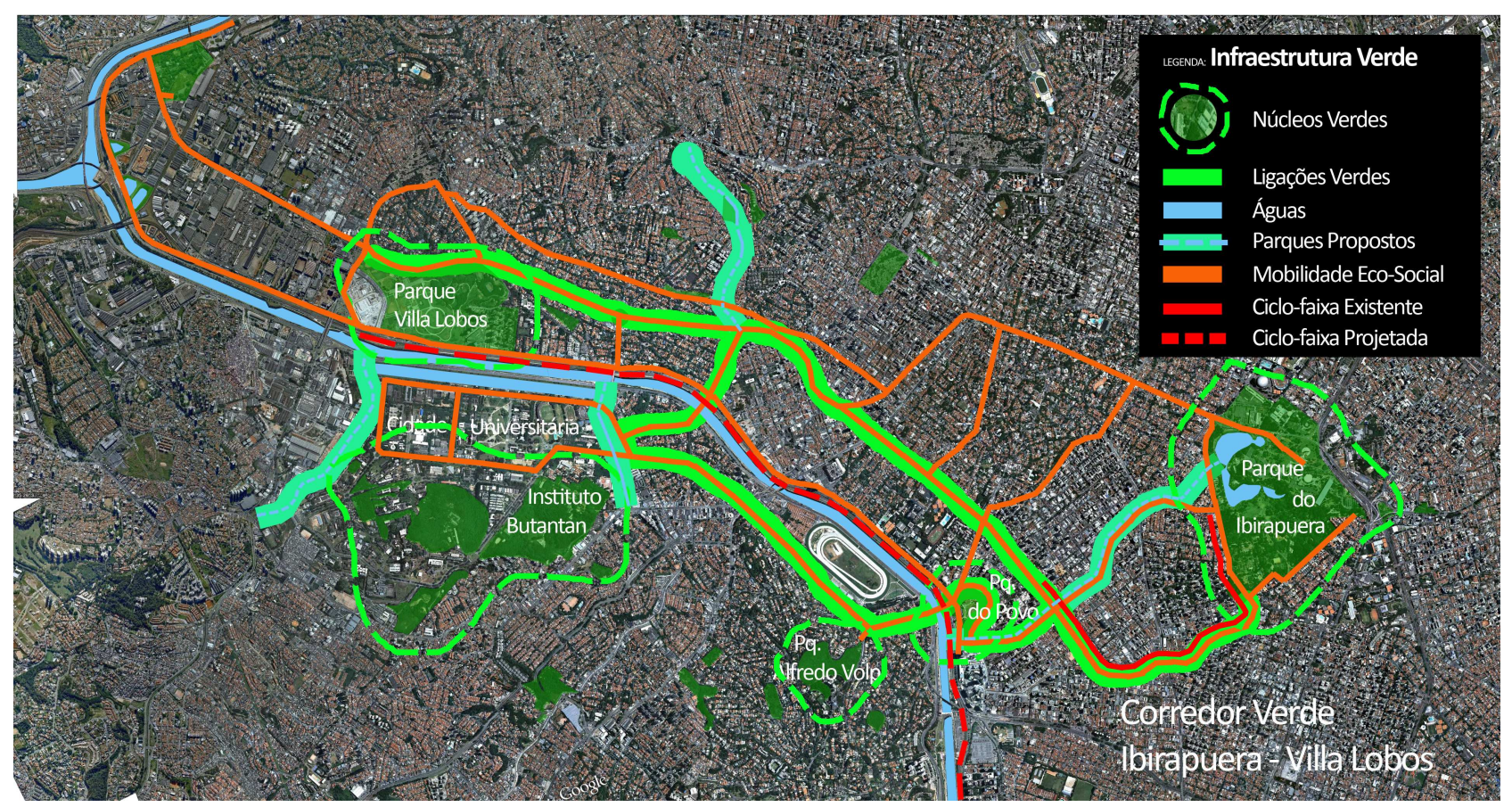

Figura 2 - Esquema conceitual da Infraestrutura Verde na várzea do rio Pinheiros

O Corredor verde lbirapuera-Villa Lobos surge dentro de um ideário por parte dos cidadãos paulistanos de "reconquista das várzeas", e no caso deste trabalho, a "reconquista da várzea do Rio Pinheiros". Como é sabido, o rio Pinheiros teve suas várzeas fortemente transformadas no correr do século $\mathrm{XX}$, pelas obras de retificação e canalização das obras de inversão de seu curso, o qual passou a alimentar as Represas Guarapiranga e Billings para a produção de energia elétrica em Cubatão. Nesse processo, perderam-se todas as áreas úmidas, ao longo de seu cordão meândrico original, em decorrência dos aterros e obras de drenagem ali realizadas, e que acabaram por subtrair da paisagem todos os cursos d'água contribuintes do rio maior, reduzindo-os a meros tubos de escoamento de águas, soterrados debaixo das "avenidas de fundo de vale". Com isso, é certo, foram ganhas ao rio enormes glebas de terreno, muitas delas habilmente reunidas pela Companhia City no planejamento dos Bairros Jardins, situados hoje nos bairros 
em estudo, de Moema, Jardim Paulistano, Pinheiros, Alto de Pinheiros e Vila Leopoldina.

Isso aconteceu num período histórico em que prevaleceu uma política de investimentos massivos em infraestrutura de energia elétrica e infraestrutura viária, esta última atrelada à predominância do automóvel (fordismo) ${ }^{34}$ e do transporte rodoviário, criando uma rede de vias, não só no território urbano e interurbano da Região Metropolitana de São Paulo, como também uma rede de estradas que cortou o Estado de São Paulo em todas as direções, criando a mais privilegiada infraestrutura rodoviária do país. Essa política, se por um lado favoreceu a mobilidade intra e inter-urbanas, por outro lado fez desaparecer da paisagem Bacia do Alto Tietê da toda a riquíssima rede hídrica, cobertura vegetal e biomas naturais que dela faziam parte. Em decorrência desse processo, a chamada Bacia de São Paulo viu transformar seu clima natural em escala regional perdendo suas características de "terra da garoa"35, transformando-se numa imensa "ilha de calor"36, capaz até de desviar as frentes frias, provenientes do polo sul, pela pressão de sua enorme cúpula de ar quente, desviando-as, muitas vezes, para o Oceano Atlântico. É sabido, que o fenômeno das ilhas de calor urbanas colabora em muito, a nível mundial, para o fenômeno das "Mudanças Climáticas"37

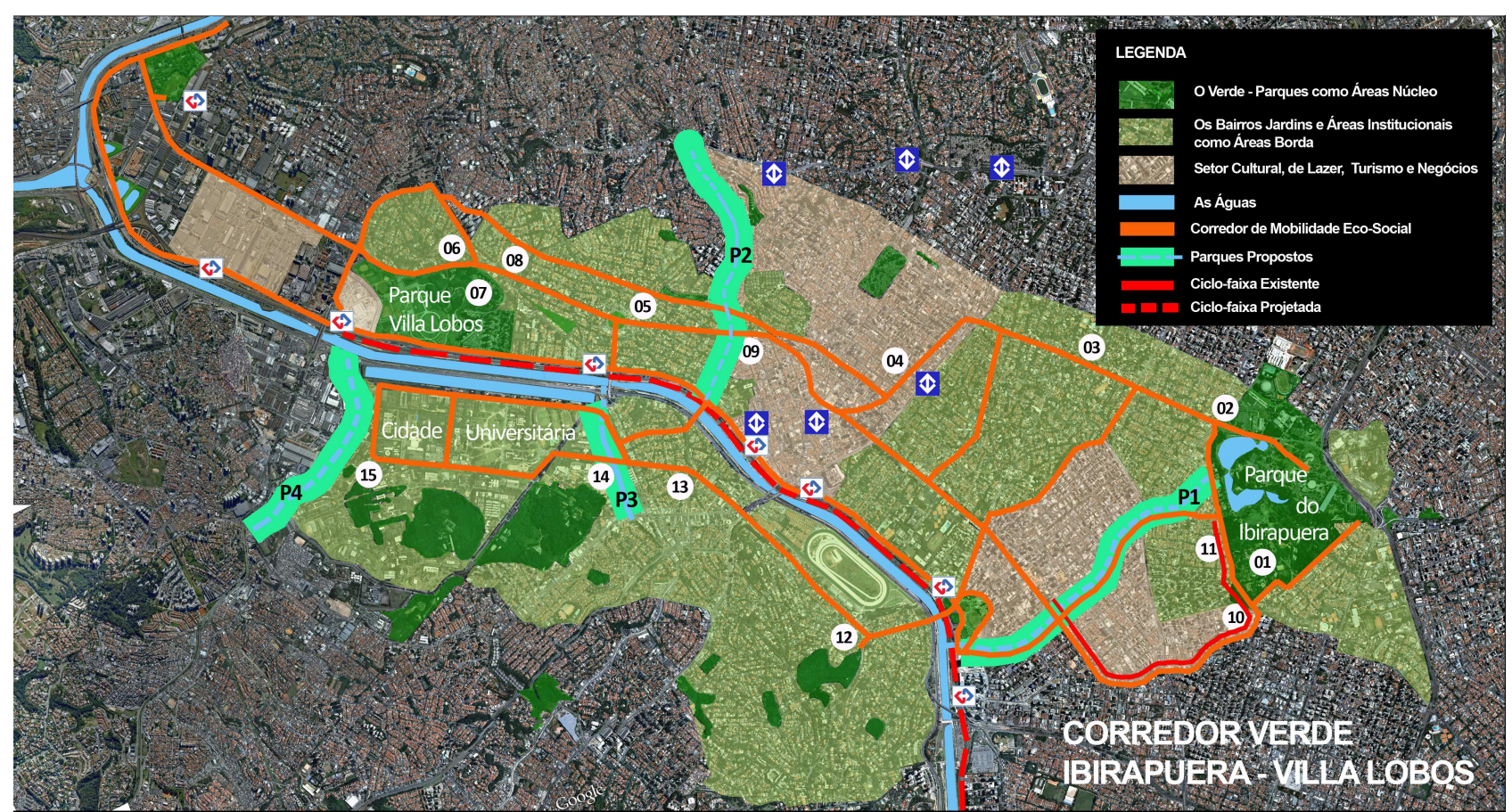

\footnotetext{
${ }^{34}$ Fordismo- termo originário do nome Ford, que designa uma política americana de expansão do automóvel em escala mundial, transformando-o, talvez, no maior "objeto de consumo" do século, e que veio a "desenhar" todas a cidades do planeta em função dos interesses da indústria automobilística e da matriz energética do petróleo.

${ }^{35}$ São Paulo "Terra da Garoa"- título alegórico e poético que a Cidade ganhou em decorrência da névoa, característica da Mata Ombrófila Úmida (Mata Atlântica), que cobria a paisagem, principalmente, ao cair da tarde ou na madrugada.

${ }^{36}$ LOMBARDO- Ilha de Calor nas Metrópoles: o Exemplo de São Paulo.

37 Mudanças Climáticas: fenômeno do aumento da temperatura da Terra, o qual provoca mudanças climáticas extremas que põem em risco a vida no Planeta, como a conhecemos hoje.
} 
Figura 3 - Infraestrutura Verde na várzea do rio Pinheiros: Corredor verde Ibirapuera-Villa Lobos

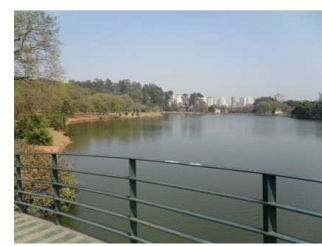

01 - Parque do lbirapuera

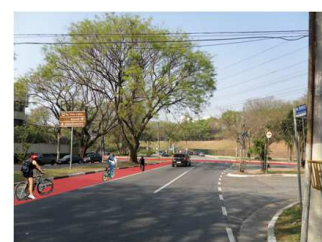

06 - Av. Padre Pereira de Andrade Entrada do Parque Villa Lobos

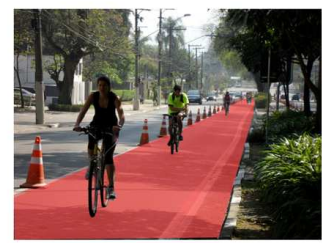

11 - Av. República do Líbano

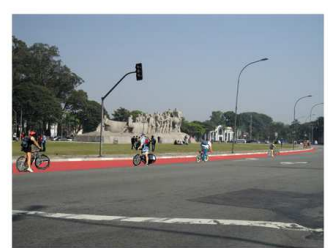

02 - Monumento às Bandeiras

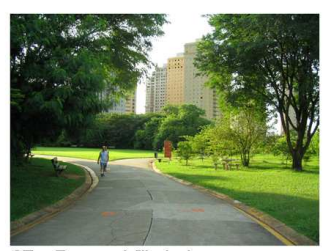

07 - Parque Villa Lobos

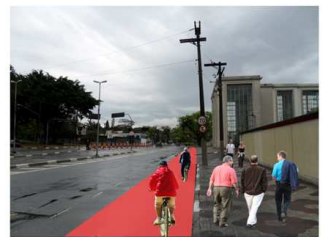

12 - Av. Lineu de Paula Machado Entrada do Jockey de São Paulo

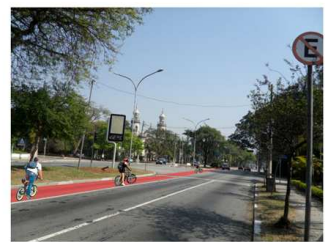

03 - Avenida Brasil

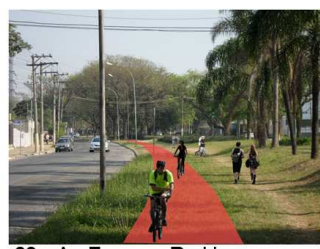

08 - Av. Fonseca Rodrigues

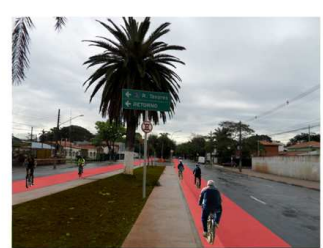

13 - Av.Valdemar Ferreira

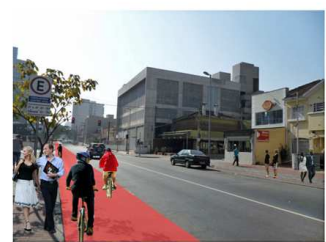

04 - Rua dos Pinheiros Estação Fradique Coutinho

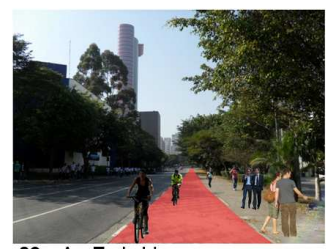

09 - Av. Faria Lima Ao fundo Instituto Tomie Ohtake

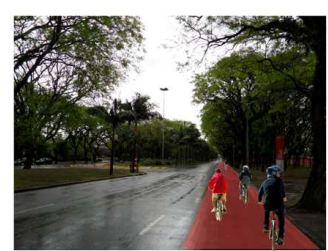

14 - Avenida da Universidade

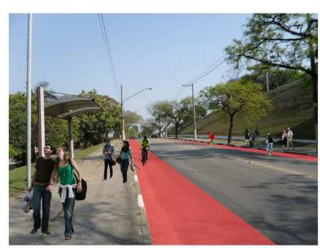

05 - Av. Diógenes Ribeiro de Lima Estrada da Boiada

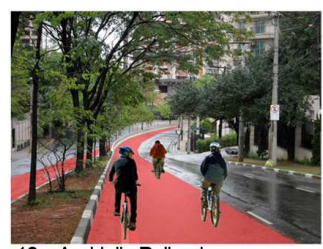

10 - Av. Helio Pellegrino

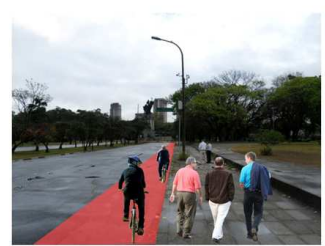

15 - Av. Prof. Luciano Gualberto

Figura 4 - Visão seriada do Corredor Verde Ibirapuera - Villa Lobos

Diante do panorama geral da Cidade de São Paulo, a área de estudo em questão é talvez a mais privilegiada em matéria de áreas verdes e iniciativas de esporte e cultura que além de várias competições atléticas e ciclísticas no correr do ano, já conquistaram trechos isolados com ciclovias, como é o caso do trecho inicial da Avenida Faria Lima, junto à Avenida Pedroso de Morais, ou mesmo o circuito ciclo-viário, que acontece aos domingos, na Avenida República do Líbano, junto à linha perimetral do Parque Ibirapuera.

No entanto, as atividades descritas bem como o modo de andar a pé ainda são muito restritas aos parques e algumas ruas arborizadas, por falta de infraestrutura verde projetada para esse fim, uma vez que tanto os pedestres quanto os ciclistas correm sérios riscos em sua integridade física e psíquica (no caso assaltos e violência).

Mesmo contando com os esforços da Prefeitura, que nos últimos anos tem reformado muitas calçadas em vários locais, principalmente nos bairros centrais, é sabido que a grande maioria das calçadas em São Paulo não apresentam condições de andar a pé, por não contarem com nivelamentos, revestimentos e equipamentos que tornam o caminhar seguro, e muito menos contam com um projeto de "arquitetura universa"l compatível. 
Um outro fator importante é que as iniciativas atuais relativas ao projeto de ciclovias não tratam do assunto com a devida atenção, ignorando o fato de que a ciclovia como qualquer modo de transporte precisa ser projetada como um sistema integrado, contando com pontos de inter-modalidade e estacionamentos para bicicletas.

Neste caso o conceito de infraestrutura verde prevê uma rede de calçadas e ciclovias que permeie a "várzea do Rio Pinheiros" devolvendo ao cidadão a reconquista dos espaços abertos urbanos propícios ao ato de caminhar e ao uso da bicicleta, modelo que uma vez experimentado poderá ser replicado em situações semelhantes por toda a cidade, contribuindo com a qualidade ambiental urbana e a qualidade de vida dos paulistanos.

\section{Conclusão}

A área de estudo denominada Corredor Verde Ibirapuera-Villa Lobos mostra-se extremamente apta à aplicabilidade dos conceitos de infraestrutura verde, mesmo porque os fatores ecossociais aí presentes mostram-se extremamente favoráveis para sua implantação. A área apresenta-se praticamente "pronta", para essa aplicação, faltando apenas as ligações entre as partes, uma vez que as áreas consideradas núcleo como os parques - Ibirapuera, Villa Lobos, Parque do Povo e Parque Alfredo Volpi - e as áreas institucionais da Cidade Universitária e do Instituto Butantã, são áreas públicas.

Logo, o trabalho comprova que o experimento realizado pelo LABVERDE, com o Corredor Verde Ibirapuera-Villa Lobos, demonstra que é possível aplicar os conceitos de infraestrutura verde e resiliência urbana no Planejamento e no Desenho Ambiental da Cidade de São Paulo.

Assim, os quatro parques lineares propostos trarão de volta o contacto com o verde e a água, na escala do pedestre, e no fruir cotidiano. O sistema ciclo-viário, interligado aos outros meios de transporte, trará mudanças de comportamento por parte da população paulistana, importantes no sentido de resiliência urbana.

O mais importante do experimento é que esse modelo poderá criar uma demanda política, por parte da população, no sentido de incrementar de fato um parque linear junto ao Rio Pinheiros, ao contrário do que aconteceu no Rio Tietê que viu 
suas margens serem revestidas de concreto e "coroadas" com floreiras, também em concreto, em escala diminuta em relação à largura do rio, não permitindo nenhuma possibilidade de aproximação do cidadão às suas margens, e excluindo, definitivamente, o trânsito de animais nas áreas ribeirinhas.

A atual apropriação das margens do Rio Pinheiros por ciclistas ${ }^{38}$ e pedestres poderá acelerar o tratamento de suas águas tornando-o limpo e livre de odores, e apto inclusive para a navegação, como foi apontado por FRANCO ${ }^{39}$. A implementação do Corredor Verde Ibirapuera Villa Lobos, embasada em resiliência, na várzea do Rio Pinheiros servirá, assim, de referência para uma nova estruturação urbana da Cidade de São Paulo com destaque em infraestrutura verde, melhorando sua qualidade ambiental e preparando-a para um melhor enfrentamento das mudanças climáticas.

\section{Bibliografia}

AMARAL, Antonio Barreto do. O Bairro de Pinheiros/Série História dos Bairros de São Paulo, V. 2. Secretaria de Educação e Cultura do Município de São Paulo. São Paulo, 1985.

BENEDICT, Mark A.; McMAHON T. Green Infrastructure: Linking Landscapes and Communities. Washington, DC; Island Press, 2009.

CZERNIAK, Julia;HARGREAVES,George. Large Parks. New York,NY. Princeton Architectural Press, 2007.

DRAMSTAD, Wenche E.; OLSON, James D.; FORMAN, Richard T.T. Landscape Ecology Principles in Landscape Architecture and Land-Use Planning. Harvard University Graduate School of Design: Island Press and ASLA, MA, U.S.A., 1996.

ETZEL, Eduardo . O Verde na Cidade de São Paulo In Revista do Arquivo Municipal; São Paulo, ano 45/№ 195/janeiro a dezembro de 1982;p49-76.

FRANCO, Maria de Assunção Ribeiro. Planejamento Ambiental para a Cidade Sustentável. São Paulo, Annablume/EDIFURB, 2ªEd., 2001.

\footnotetext{
${ }^{38} \mathrm{O}$ texto refere-se à atual ciclo-faixa entre a represa Guarapiranga e a Av. Bandeirantes.

${ }^{39}$ FRANCO, op. cit. cap. IX.
} 
Desenho Ambiental - Introdução à Arquitetura da Paisagem com o

Paradigma Ecológico. 2a․ Edição, São Paulo, Annablume: Fapesp, 2008.

GUNDERSON, L. H.; L. Pritchard. Resilience and the Behavior of Large Scale Ecosystems. Scope Volume. Island Press, Washington, DC., 2009.

LOMBARDO, Adelaide Lombardo. Ilha de Calor nas Metrópoles: o Exemplo de São Paulo. São Paulo, Hucitec, 1985.

MALATESTA, Maria Ermelina Broch. Andar a pé: Um modo de Transporte para a Cidade de São Paulo. Dissertação de Mestrado apresentada à Faculdade de Arquitetura e Urbanismo da Universidade de São Paulo. São Paulo, 2007.

MIGLIONICO, Rosa Itálica. Parque do Ibirapuera: Um Ícone da Paisagem Paulistana. Tese de Doutorado apresentada à Faculdade de Arquitetura e Urbanismo da Universidade de São Paulo. São Paulo, 2007.

NEWMAN, Peter; BEATLEY,Timothy; BOYER, Heather. Resilient Cities: Responding to Peak Oil and Climate Change. Washington, DC, Island Press, 2009.

ROCHA, Alice Fernandes. O Parque Villa Lobos: Área Verde Memorável da Cidade de São Paulo. Monografia de Especialização apresentada à Faculdade de Arquitetura e Urbanismo da Universidade Presbiteriana Mackenzie. São Paulo, 2008.

SÃo PAULO (Estado) Secretaria do Meio Ambiente/Secretaria Municipal de Planejamento. Vegetação Significativa do Município de São Paulo, São Paulo, 1988.

SÃO PAULO (Município), Secretaria Municipal de Planejamento Urbano /Secretaria Municipal do Verde e Meio Ambiente. Atlas Ambiental do Município de São Paulo. São Paulo, 2002.

SÃO PAULO (Município), Secretaria do Vede e de Meio Ambiente/Departamento de Parques e Áreas Verdes. Guia dos Parques Municipais de São Paulo, São Paulo, 2007. 